\title{
Concept of Formae Speciales in Sclerotium rolfsii, a Collar Rot Pathogen of Crop Plants and its Use in Crop Diversification System
}

\author{
SG Borkar ${ }^{1 *}$ and SP Gawande ${ }^{2}$ \\ ${ }^{1}$ Plant Disease Diagnostic Laboratory and Research Center, Nashik Road, Maharashtra state, India \\ ${ }^{2}$ Plant Pathology Division, Central Cotton Research Institute, Indian Council of Agriculture Research, Wardha road, Nagpur, \\ Maharashtra state, India
}

*Corresponding author: SG Borkar, Plant Disease Diagnostic Laboratory and Research Center, Nashik Road, Maharashtra state, India

\section{ARTICLE INFO}

Received: August 19, 2021

Published: 幽 August 27, 2021

Citation: SG Borkar, SP Gawande. Concept of Formae Speciales in Sclerotium rolfsii, a Collar Rot Pathogen of Crop Plants and its Use in Crop Diversification System. Biomed J Sci \& Tech Res 38(3)-2021. BJSTR. MS.ID.006151.

\begin{abstract}
Sclerotium rolfsii, a soil dwelling fungal plant pathogen causing seedling mortality/ collar rot disease in crop plants have a wider host range of cereals, millets, pulses, oilseeds, fibre crop, vegetables, fruit crops, medicinal, spices, flowering plants and forest trees to cause plant mortality and yield losses in fields and storages around the world. Sclerotium rolfsii, as a single pathogen infect all these crop species or there is variation among the isolates infecting these crop species and thereby presence of formae speciales in this pathogen, is not yet known. In our studies 13 isolates of Sclerotium rolfsii isolated from different crop species comprising cereal, pulses, oilseed, vegetables, medicinal plant, and flowering plant were test inoculated on 27 different crop species of above plants for their susceptibility to determine the host range of these individual/ particular isolate. On the basis of host-Pathogen interaction, leading to seedling mortality/collar rot disease at least 11 formae speciales of this pathogen viz. f.sp.ciceri, f.sp.glycinae, f.sp. betae, f.sp.gossypi, f.sp. plantago, f.sp. mangeferae, f.sp. lagenariae, arachis, polianthes, dahlia and lilium were established. Sclerotium rolfsii isolates from Chickpea, Wheat and Tomato had the same host range, and therefore inclusion of further different crops in host range studies will established the presence of formae speciales in the isolates from chickpea, wheat and tomato. Based on host range studies of these isolates/f. sp. a crop diversification system is proposed so as to avoid the infection in crop plants in the Sclerotium rolfsii infected fields. These results have a great significance in planning the crop cultivation in Sclerotium rolfsii sick soils.
\end{abstract}

Keywords: Sclerotium rolfsii; Formae Speciales; Pathogenic Variability; Host Specificity; Crop Diversification; Collar Rot Management

\section{Introduction}

A soil dwelling fungal pathogen Sclerotium rolfsii (Athelia rolfsii, belonging to phylum Basidiomycota, sub-phylum Agaricomycotina and class Agaricomycetes) causing seedling mortality/root rot/ collar rot is a widely distributed pathogen of crop plants around the world. Its presence is reported from 45 countries in Africa region, 28 countries in Asian region, 16 countries in Europe, 28 countries in
North America, 11 countries in South America and 13 countries in Oceania region. The detail and updated list up to July 2021 of these countries are available on CABI website [1]. In USA the pathogen is widespread and reported from 33 states while in India it is reported from 24 states including Union territories [1]. The infection of the pathogen is severe in some crops (Figure 1) whereas sporadic in others, where it causes either collar rot, root rot, wilt, seedling 
blight etc depending on the host plant. The losses caused by this pathogen are severe in term of yield losses, e.g. in North Carolina state in USA, the peanut crop suffered higher losses than any other agricultural crop. The USDA estimated losses of US\$ 10 million to 20 million in Southern peanut growing region with yield depletion of $1-60 \%$ in the fields of North Carolina coastal plains region due to Sclerotium rolfsii infection [2]. In India, the yield losses in peanut field is reported over 25\% [3]. In betel-vine gardens the plant losses is reported from $40-62 \%$ [4]. The post- harvest losses in storage and transit by this pathogen for ginger and elephant yam is $35 \%$, for Carrot and Ladyfinger it is $30 \%$ and in beet, pumpkin, potato and bottle-gourd these are at 25,20, 15 and 12\% respectively in West Bengal [5]. The pathogen is continuously making its impact on the crop plant since its first report on tomato in 1892 till today [6].

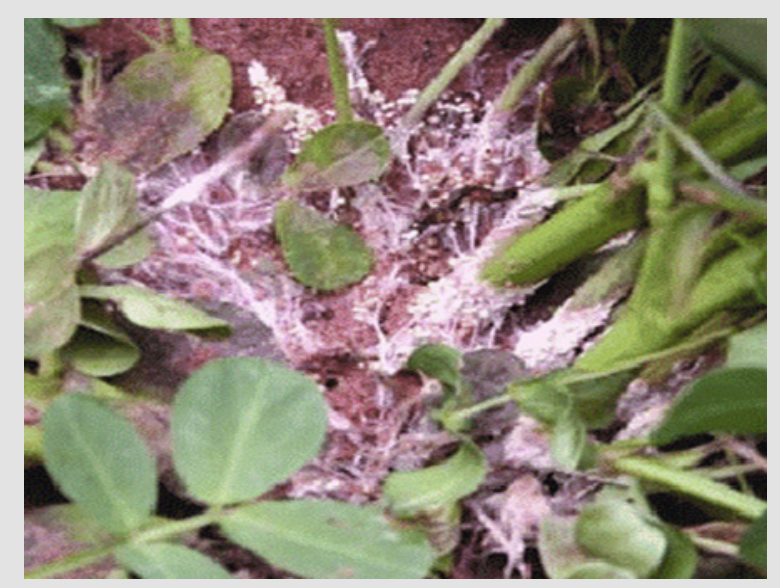

Figure 1: Infection of Sclerotium rolfsii on groundnut crop.

The pathogen has a wide host range infecting the cereals $[7,8]$, Pulses [9,10], Oilseeds [11-14], Fibre crops [15], Vegetables [1622], Fruits crop [23], Spices [24], Medicinal and aromatic plants [25,26], Flowering plants [27,28], Forest tress seedlings [29] and others [30]. Thus, the pathogen Sclerotium rolfsii, as a single pathogen infect all these crop species or there is variation among the isolates infecting these crop species and thereby presence of formae speciales in this pathogen, is not yet known. Therefore, studies on host range of Sclerotium rolfsii isolated from different crop species were studied with an aim to determine the variability in the pathogen and detection of formae speciales among Sclerotium rolfsii infecting various crop species. Further, on the basis on host range a crop diversification system was derived for Sclerotium rolfsii infected soil to bring such soils in crop cultivation without causing Sclerotium diseases in cultivated crop in such soils.

\section{Materials and Methods}

\section{Isolation / Collection of Different Isolates of Sclerotium rolfsii}

Sclerotium rolfsii from collar rot disease plants of chickpea, soybean, sugar-beet, wheat, cotton, groundnut, tomato, bottle gourd, Isabgol (Psyllium), Tuberose, Dahlia and Lilly, collected from diverse geographic locations of Western Maharashtra state, India, were isolated on potato-dextrose-agar (PDA) medium. Isolations were made from the fresh diseased plant samples collected at seedling / vegetative stage of the crop. The infected sample bits were surface sterilized with 0.1 percent mercuric chloride $\left(\mathrm{HgCl}_{2}\right)$ solution followed by thorough washing (three times) with sterile distilled water, dried gently by placing in between the two sterile blotter paper and then placed on sterilized PDA medium in Petri dish for isolation of the pathogenic fungus. These petri-plates were then incubated at $28 \pm 2{ }^{\circ} \mathrm{C}$ in BOD incubator. Mycelial growth radiating from infected bits was further sub-cultured on the same medium to obtain the full fungal growth and sclerotial fruiting bodies of the pathogen. To obtain the pure culture of the respective isolates, the single sclerotial body from the isolate was grown in petri-plate/test tube slant on PDA and maintained as pure culture of the respective isolate.

\section{Mass Multiplication of Different Sclerotium rolfsii Isolates for Host Range Studies}

Mass multiplication of different Sclerotium rolfsii isolates (Figure 2) was made by following the method suggested by Borkar and Chaudhary [8]. The individual Sclerotium rolfsii culture isolated from different host was grown separately on Wheat-SorghumSoybean grain medium (Wheat 500g; Sorghum 250g; Soybean 250 g; $\mathrm{CaCo}_{3}-25 \mathrm{~g}$.). This was prepared by soaking grains of Wheat, Sorghum and Soybean in water for overnight and then cooked in boiling water for $20 \mathrm{~min}$, the excess water was drained out and the grains were dried in shed for $30 \mathrm{~min}$. All grains were mixed well with $\mathrm{CaCo}_{3}$ and filled into the glass bottles $(500 \mathrm{ml})$. These were autoclaved at $15 \mathrm{lbs}$ pressure for $30 \mathrm{~min}$. The autoclaved sterilized grain medium in bottles was inoculated with Sclerotium rolfsii cultures separately and incubated at $28 \pm 0.5^{\circ} \mathrm{C}$ for its growth. After thirty days of incubation (the whole grain medium get covered with mycelium and sclerotial bodies.), these cultures were used for pathogenicity test on respective host plant and Host range studies. 

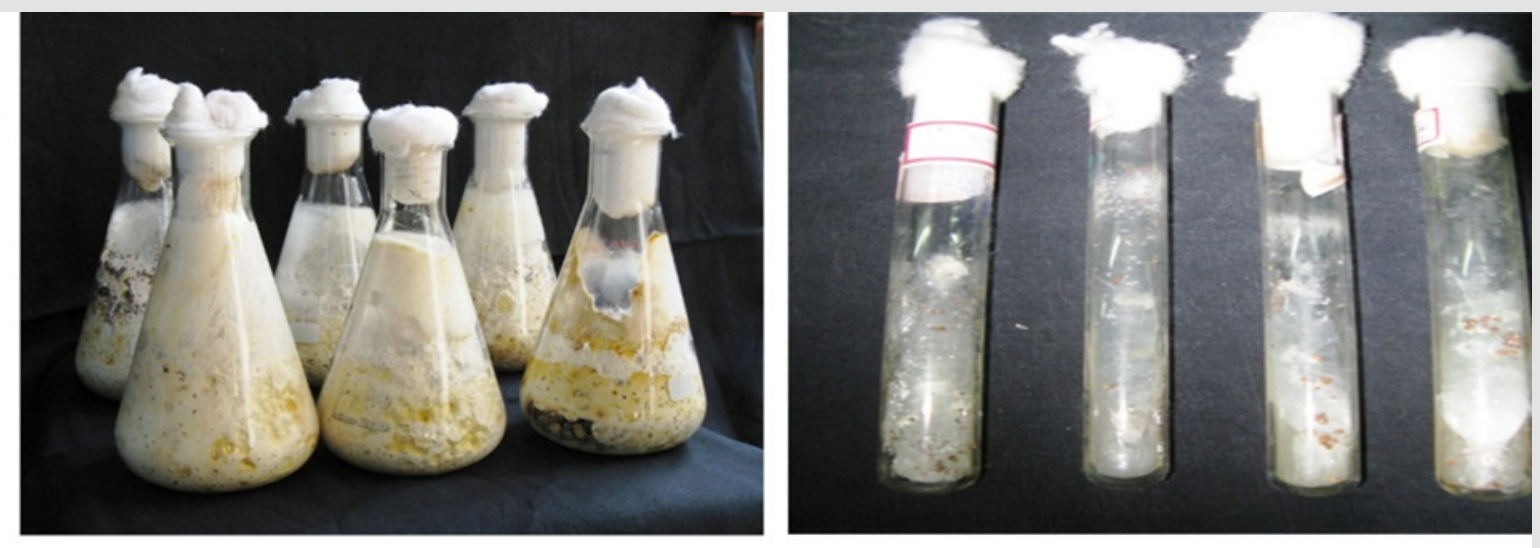

Figure 2: Mass multiplication of S.rolfsii f.sp. isolates.

\section{Studies on Host Specificity of Different Host Isolates of $S$. rolfsii by Cross Inoculation Method}

Thirteen different Sclerotium rolfsii isolates obtained as disease pathogen from Chickpea, Soybean, sugar beet, Isabgol, Mango, Bottle gourd, Wheat, Cotton, Groundnut, Tomato, Tuberose, Dahlia and Lily were tested for their pathogenicity on their respective host plant. Further, these thirteen isolates were tested for their host specificity and host range by cross inoculation on 27 different crop species plants belonging to cereals, millet, pulses, oilseeds, fibre crop, vegetables crop, medicinal plant, and flowering plants. These plants included Wheat, Pearl millet, Rice, Maize, Gram, Moth bean, Pigeon pea, Pea, Green gram, black gram, Soybean, Linseed, Cotton, Sun hemp, Sunflower, Jute, Groundnut, Sugar beet, Isabgol, Brinjal, Chilli, Bottle gourd, Tomato, Onion, Lily, Mango and Tuberose. The soil tray technique of Backman, et al. [31] was used in this study. The wooden trays of $4 \times 3 \times 0.5$ feet size was used for these studies (Figure 3). Different isolates of Sclerotium rolfsii were mass multiplied as stated previously and the individual trays was filled with $120 \mathrm{Kg}$ well mixed material consisting of sterilized soil + FYM $(3: 1)+800 \mathrm{gm}$ inoculum of Sclerotium rolfsii of concerned isolate. The whole soil - $S$. rolfsii mixture was kept moist and humid by sprinkling water on it intermittently and covering with polythene sheet. This was allowed to incubate for 15 days for profuse growth and multiplication of the $S$. rolfsii inoculum. The profuse growth thus obtained of the pathogen was thoroughly mixed into the soil for maintaining uniform inoculum in the soil. The control treatment maintained was of sterilized soil + FYM (3:1) without inoculum. The seeds of different hosts/planting material (as the case may be) for 27 crop species as mentioned above were either sown or planted in each tray consisting of individual $S$. rolfsii isolate. The observations regarding germination of seed and mortality of seedling or infection on seedling /grafts were taken up to 45 days at a weekly interval from the date of sowing / planting.
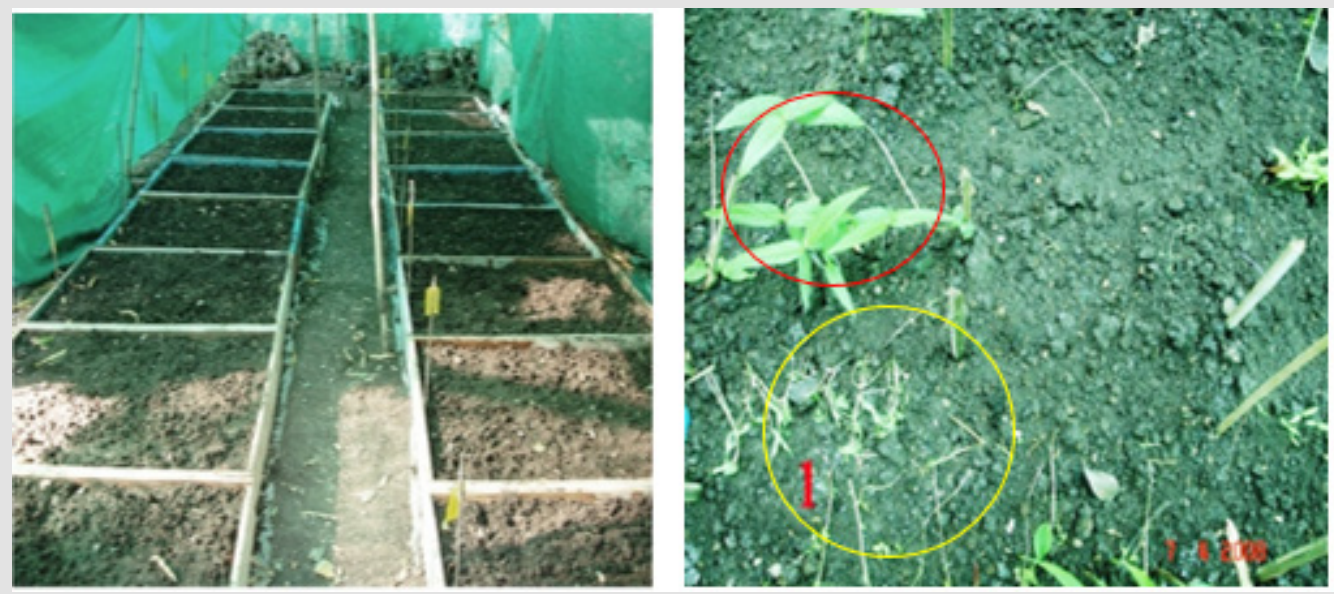

Figure 3: Soil tray with Sclerotium rolfsii f.sp. inoculum and host range studies. Red circle shows healthy crop plant while yellow circle shows diseased rotted crop plant in the same S. rolfsii f.sp. inoculum. 


\section{Result and Discussion}

\section{Host Specificity/Host Range of Different S. rolfsii Isolates}

None of the isolate of Sclerotium rolfsii was strictly host specific, rather they could infect other number of hosts. The $13 \mathrm{~S}$. rolfsii isolates obtained from different host plants and tested for their host range against 27 different crop species revealed that different isolates have different host range (Table 1). However, the isolates from Chickpea, Tomato and Wheat had the same host range and therefore is to be considered as the same isolate. These three isolates could not infect Sun hemp, Lily, Mango, and Tuberose. The Soybean isolate could not infect Lily, Mango and Tuberose plant. Sugar beet isolate could not infect Maize, Green gram, Black gram, Cotton, Sun hemp, Bottle gourd, Lily, Mango, and Tuberose. The Isabgol isolate could not infect the Maize, Pea, Green gram, Lily, Mango and Tuberose. The Mango isolates could not infect Pea, Green gram, Black gram, Soybean, Sun hemp, Chilli, Bottle gourd,

Tomato, Onion, Lily and Tuberose. However, it was interesting to note that all the isolates could infect their respective host from which these were isolated. In case of Tuberose isolate it could not infect Paddy, Maize, Bottle gourd and all five fruits and ornamental plants. The isolate of Bottle gourd have very narrow host range and could not infect Maize, Red gram, Soybean, Sun hemp, Jute, Onion, Groundnut and test fruits and Ornamental host plant. The Cotton isolate could not infect Black gram, Soybean, Sun hemp, Bottle gourd, Groundnut and test fruits and ornamental host plant. Similarly the groundnut isolate could not infect Paddy, Maize and the tested fruits and ornamental host plant i.e. Lily and tuberose. Dahlia isolate could not infect Maize, Sun hemp, Tomato and Lily plant, whereas Lily isolate could not infect Paddy, Maize, Soybean, Sun hemp, Groundnut, Onion and Mango. Thus, different isolates showed variation in its pathogenicity when cross inoculated on several other crops.

Table 1: Determination of host range of Sclerotium rolfsii isolates of different crops by cross inoculation test.

\begin{tabular}{|c|c|c|c|c|c|c|c|c|c|c|c|c|c|c|c|c|c|c|c|c|c|c|c|c|c|c|c|c|}
\hline \multirow[b]{2}{*}{$\begin{array}{l}\text { Sr. } \\
\text { No }\end{array}$} & \multirow[b]{2}{*}{$\begin{array}{l}\text { S. rolfsii } \\
\text { Isolate of }\end{array}$} & \multicolumn{27}{|c|}{ Reaction on crop plants } \\
\hline & & $\frac{\pi}{3}$ & 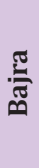 & 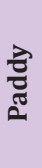 & $\sum^{\frac{N}{\pi}}$ & 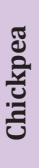 & 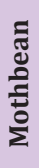 & 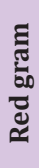 & 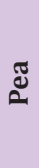 & 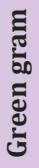 & 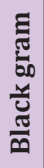 & 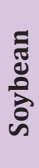 & 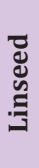 & 율 & 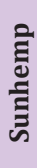 & 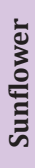 & $\stackrel{\Xi}{\Xi}$ & 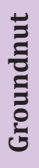 & 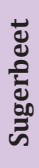 & 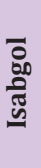 & 祍 & 豙 & 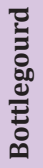 & 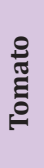 & 。ِ & $\stackrel{2}{3}$ & 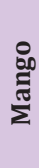 & 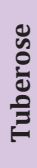 \\
\hline 1 & Chickpea & + & + & + & + & + & + & + & + & + & + & + & + & + & - & + & + & + & + & + & + & + & + & + & + & - & - & - \\
\hline 2 & Soybean & + & + & + & + & + & + & + & + & + & + & + & + & + & + & + & + & + & + & + & + & + & + & + & + & - & - & - \\
\hline 3 & Sugar beet & + & + & + & - & + & + & + & + & - & - & + & + & - & - & + & + & + & + & + & + & + & - & + & + & - & - & - \\
\hline 4 & Isabgol & + & + & + & - & + & + & + & - & - & + & + & + & + & + & + & + & + & + & + & + & + & + & + & + & - & - & - \\
\hline 5 & Mango & + & + & + & + & + & + & + & - & - & - & - & + & + & - & + & + & + & + & + & + & - & - & - & - & - & + & - \\
\hline 6 & $\begin{array}{l}\text { Bottle } \\
\text { gourd }\end{array}$ & + & + & + & - & + & + & - & - & + & + & + & + & - & - & + & - & - & + & + & + & + & + & + & - & - & - & - \\
\hline 7 & Wheat & + & + & + & + & + & + & + & + & + & + & + & + & + & - & + & + & + & + & + & + & + & + & + & + & - & - & - \\
\hline 8 & Cotton & + & + & + & - & + & + & + & + & + & - & - & + & + & - & + & + & - & + & + & + & + & - & + & + & - & - & - \\
\hline 9 & Groundnut & + & + & - & - & + & + & + & + & + & + & + & + & + & + & + & + & + & + & + & + & + & + & + & + & - & - & - \\
\hline 10 & Tomato & + & + & + & + & + & + & + & + & + & + & + & + & + & - & + & + & + & + & + & + & + & + & + & + & - & - & - \\
\hline 11 & Tuberose & + & + & - & - & + & + & + & - & + & + & + & + & + & - & + & + & - & + & + & + & + & + & + & - & - & - & + \\
\hline 12 & Dahlia & + & + & - & - & + & + & + & + & + & + & + & + & + & - & + & + & + & + & + & + & + & + & - & + & - & + & - \\
\hline 13 & Lilly & + & + & - & - & + & + & + & + & + & + & - & + & + & - & + & + & - & + & + & + & + & + & + & - & + & - & - \\
\hline 14 & Control & - & - & - & - & - & - & - & - & - & - & - & - & - & - & - & - & - & - & - & - & - & - & - & - & - & - & - \\
\hline
\end{tabular}

Note: + = Diseased (Mortality of seedling/plants), - = No disease (Healthy Plant).

Geographical variation among Sclerotium rolfsii population in respect of growth rate, fungal morphology, sclerotial bodies and their formation has been studied by several workers [32-38], but the research on pathogenic variability among such populations are lacking. Though variability in oxalic acid production among different isolates of S.rolfsii [39] as well as genetic variability among these isolates in western Maharashtra was studied [40], the results on pathogenic variability within Sclerotium rolfsii in the geographical region is not yet available. Such studies are important because these form the basis to know the host range of the given Sclerotium rolfsii, so as to formulate the cropping systems to avoid the infection of the pathogen and in the management of the crop disease. This will also help to know the different sub-species/formae speciales present in Sclerotium rolfsii population in the geographical region.

\section{Scheme for Identification of Formae Speciales of Sclerotium rolfsii on Differential Host Plant}

On the basis of 12 differential host used for the identification of formae-speciales of $S$. rolfsii and the reaction of the host to 
the pathogen, at least 11 formae-speciales of this pathogen viz. f.sp.ciceri, f.sp.glycinae, f.sp. betae, f.sp.gossypi, f.sp. plantago, f.sp. mangeferae, f.sp. lagenariae, arachis, polianthes, dahlia and lilium (Table 2) were identified for 13 different host isolates. At present three S. rolfsii isolates viz., from Tomato, Wheat and Chickpea showed similar reaction on these differential hosts and therefore considered as a same formae-speciales i.e f.sp. ciceri. This is the first report of identification of formae speciales in the Sclerotium rolfsii pathogen

Table 2: Identification of sub-species of Sclerotium rolfsii on differential host plant.

\begin{tabular}{|c|c|c|c|c|c|c|c|c|c|c|c|c|c|}
\hline \multirow[b]{2}{*}{$S$. rolfsii isolate of } & \multicolumn{12}{|c|}{ Reaction on Differential Host Plants } & \multirow[b]{2}{*}{$\begin{array}{l}\text { S. rolfsii } \\
\text { f. sp. }\end{array}$} \\
\hline & $\frac{\overrightarrow{2}}{\frac{\pi}{7}}$ & 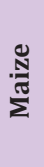 & 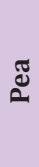 & 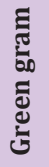 & 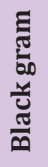 & 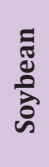 & ن̊ & है & 竓 & 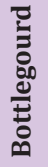 & 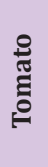 & $\stackrel{\Xi}{\Xi}$ & \\
\hline Soybean & + & + & + & + & + & + & + & + & + & + & + & + & Glycine \\
\hline Sugar beet & + & - & + & - & - & + & - & - & + & - & + & + & Betae \\
\hline Isabgol & + & - & - & - & + & + & + & + & + & + & + & + & Plantago \\
\hline Mango & + & + & - & - & - & - & + & - & - & - & - & - & Mangiferae \\
\hline Bottle gourd & + & - & - & + & + & + & - & - & + & + & + & - & Lagenariae \\
\hline Wheat / Tomato / Chickpea & + & + & + & + & + & + & + & - & + & + & + & + & Ciceri \\
\hline Cotton & + & - & + & + & - & - & + & - & + & - & + & + & Gossypi \\
\hline Groundnut & - & - & + & + & + & + & + & + & + & + & + & + & Arachis \\
\hline Tuberose & - & - & - & + & + & + & + & - & + & + & + & - & Polianthes \\
\hline Dahlia & - & - & + & + & + & + & + & - & + & + & - & + & Dahlia \\
\hline Lily & - & - & + & + & + & - & + & - & + & + & + & - & Lilium \\
\hline
\end{tabular}

Note: $+=$ development of disease i.e., Root rot / collar rot

- = No disease development

\section{Crops Susceptible to Sclerotium rolfsii f.sp.}

Table 3: Crops susceptible to different $f$. sp of Sclerotium rolfsii.

\begin{tabular}{|c|c|c|}
\hline Sr. No & Sclerotium rolfsii f.sp. & Crop Plants Infected \\
\hline 1. & f.sp. ciceri & $\begin{array}{l}\text { Chickpea, Wheat, Pearl millet, Paddy, Maize, Pea, Red gram, Green Gram, Black Gram, Soybean, Moth bean, Cotton, } \\
\text { Linseed, Groundnut, Sunflower, Sugar beet, Isabgol, Jute, Chilli, Tomato, Brinjal, Onion, Bottle gourd, }\end{array}$ \\
\hline 2. & f.sp. glycinae & $\begin{array}{l}\text { Soybean, Chickpea, Wheat, Pearl millet, Paddy, Maize, Pea, Red gram, Green Gram, Black Gram, Moth bean, Cotton, } \\
\text { Linseed, Groundnut, Sunflower, Sugar beet, Isabgol, Jute, Sun hemp, Chilli, Tomato, Brinjal, Onion, Bottle gourd }\end{array}$ \\
\hline 3 & f. sp. betae & $\begin{array}{c}\text { Sugar beet, Wheat, Pearl millet, Paddy, chickpea, Moth bean, Red gram, Pea, Soybean, Linseed, Sunflower, Ground- } \\
\text { nut, Jute, Isabgol, Brinjal, Chilli, Tomato, Onion }\end{array}$ \\
\hline 4 & f. sp. gossypi & $\begin{array}{c}\text { Cotton, Wheat, Pearl millet, Paddy, chickpea, moth bean, red gram, Pea, Green Gram, linseed, sunflower, jute, sugar } \\
\text { beet, Isabgol, brinjal, Chilli, Tomato, Onion }\end{array}$ \\
\hline 5 & f.sp.plantago & $\begin{array}{l}\text { Isabgol, Wheat, Pearl millet, Paddy, chickpea, moth bean, red gram, Black Gram, Soybean, linseed, Cotton,, Sun } \\
\text { hemp, sunflower, jute, groundnut, sugar beet, brinjal, Chilli, Tomato, Onion, Bottle gourd }\end{array}$ \\
\hline 6 & f. sp. mangeferae & $\begin{array}{l}\text { Mango, Wheat, Pearl millet, Paddy, Maize, Chickpea, moth bean, red gram, linseed, Cotton, Sunflower, Jute, } \\
\text { Groundnut, Sugar beet, Isabgol, Brinjal. }\end{array}$ \\
\hline 7. & f. sp. lagenariae & $\begin{array}{l}\text { Bottle gourd, wheat, Pearl millet, Paddy, chickpea, moth bean, Green Gram, Black Gram, Soybean, linseed, sunflow- } \\
\text { er, sugar beet, isabgol, brinjal, Chilli, Tomato, Bottle gourd }\end{array}$ \\
\hline 8. & f. sp. arachis & $\begin{array}{l}\text { Groundnut, wheat, Pearl millet, chickpea, moth bean, red gram, pea, Green Gram, Black Gram, Soybean, linseed, } \\
\text { cotton, sun hemp, sunflower, jute, sugar beet, isabgol, brinjal, Chilli, Tomato, Bottle gourd, onion. }\end{array}$ \\
\hline 9. & f. sp. polianthes & $\begin{array}{l}\text { Tuberose, wheat, Pearl millet, chickpea, moth bean, red gram, Green Gram, Black Gram, Soybean, linseed, cotton, } \\
\text { sunflower, jute, sugar beet, isabgol, brinjal, Chilli, Tomato, Bottle gourd }\end{array}$ \\
\hline 10. & f. sp. dahlia & $\begin{array}{l}\text { Dahlia, wheat, Pearl millet, chickpea, moth bean, red gram, pea, Green Gram, Black Gram, Soybean, linseed, cotton, } \\
\text { sunflower, jute, groundnut, sugar beet, isabgol, brinjal, Chilli, Bottle gourd, onion. }\end{array}$ \\
\hline 11. & f. sp. lilium & $\begin{array}{l}\text { Lilium, wheat, Pearl millet, chickpea, moth bean, red gram, Green Gram, Black Gram, linseed, cotton, sunflower, } \\
\text { jute, sugar beet, isabgol, brinjal, Chilli, Tomato, Bottle gourd }\end{array}$ \\
\hline
\end{tabular}


The 11 formae speciales of Sclerotium rolfsii, besides their natural host plant infect other crop species and therefore, these crops should not to be grown in the specific formae speciales infected soils (Table 3 ) to avoid the infection of collar rot disease and yield losses. There are reports from India and elsewhere that the host range of this pathogen is increasing and thereby poses great threat to the crop grower [41] to know exactly which crop they should grow in such $S$. rolfsii infected soils and therefore need a crop diversification system.

\section{Crop Diversification for $S$, rolfsii Infected Soils}

Based on the host range studies of different S.rolfsii f.speciales, the crop diversification system is proposed for the respective Sclerotium rolfsii infected soil (Table 4). The soils having Sclerotium rolfsii (f.sp.ciceri) of Chickpea / Tomato / Wheat are only suitable for green manure crop like Sun hemp, flowering crops like Lily and Tuberose and horticultural crop like Mango. The soils having Sclerotium rolfsii (f.sp.arachis) of Groundnut are only suitable for Paddy, Maize, Lily, Tuberose and Mango. Soils infected with Sugar beet Sclerotium rolfsii (f.sp.betae) are suitable for Maize, Green gram, Black gram, Cotton, Sun hemp, Bottle gourd, Lily, Mango, and Tuberose. The soils infected with soybean collar rot pathogen (f.sp. glycinae) are only suitable for growing lilium, tuberose and mango. The soils infected with collar rot pathogen of cotton (f.sp. gossypi) are suitable for growing Maize, Black gram, soybean, sun hemp, groundnut, bottle gourd, lilium, tuberose and mango. The soils infected with collar rot pathogen of Bottle gourd (f.sp.lagenariae) are suitable for growing Maize, Red gram, Pea, Cotton, Sun hemp, Jute, Onion, Mango, Groundnut, Lily, tuberose. The soils infected with collar rot pathogen of Isabgol (f.sp. plantago) are suitable for growing Maize, Pea, Green gram, Mango tuberose and lilium. The soils infected with collar rot pathogen of mango (f.sp. mangeferae) are suitable for growing pea, green gram, black gram, soybean, sun hemp, chilli, bottle gourd, tomato, onion, tuberose and lilium. The soils infected with collar rot pathogen of dahlia are suitable for growing paddy, maize, sun hemp, tomato, lily and tuberose. The soils infected with collar rot pathogen of lily (f.sp.lilium) are suitable for growing paddy, maize, soybean, sun hemp, groundnut, onion, mango and tuberose while the soils infected with collar rot pathogen of tuberose (f.sp.polianthes) are suitable for growing paddy, maize, pea, sun hemp, groundnut, onion, lily and mango. The crop diversification system for $S$. rolfsii infected soils are proposed for the first time and beneficial to the crop cultivators encountering the disease problem of $S$. rolfsii.

Table 4: Crop diversification for S. rolfsii infected soil.

\begin{tabular}{|c|c|c|}
\hline Sr. No. & Soil having Sclerotium rolfsii of & Host Plants for Crop Diversification/Rotation \\
\hline 1 & Chickpea/Tomato/Wheat & Sun hemp, Lily, Mango, Tuberose \\
\hline 2 & Soybean & Lily, mango, tuberose \\
\hline 2 & Sugar beet & Maize, Green gram, Black gram, Cotton, Sun hemp, Bottle gourd, Lily, Mango, Tuberose \\
\hline 4 & Cotton & Maize, Black gram, Soybean, Sun hemp, Bottle gourd, Groundnut, Lily, Mango, Tuberose \\
\hline 5 & Isabgol & Maize, Pea, Green gram, Lily, Mango, Tuberose, \\
\hline 6 & Mango & Pea, Green gram, Black gram, Soybean, Sun hemp, Chilli, Bottle gourd, Tomato, Onion, Lily, \\
\hline 7 & Tuberose \\
\hline 8 & Groundnut & Maize, Red gram, Pea, Cotton, Sun hemp, Jute, Onion, Mango, Groundnut, Lily, Tuberose \\
\hline 9 & tuberose & Paddy, Maize, Lily, Mango, Tuberose \\
\hline 10 & Dahlia & Paddy, maize, pea, sun hemp, groundnut, onion, lily, mango \\
\hline 11 & Lily & Paddy, Maize, Sun hemp, Tomato, Lily, Tuberose \\
\hline
\end{tabular}

\section{Conclusion and Recommendation}

A Sclerotium rolfsii formae speciales specific crop host range is made available with this research paper. The crop growers having S. rolfsii infected soil, can grow any crop mentioned in the crop diversification system to avoid the disease infection and crop losses. Similarly, they can check their field infected soils themselves in a pot/trays by sowing the seeds of their proposed crop in these pots/ trays and observe whether the same succumb to the pathogen. In case, it won't succumb, they can go for the field cultivation of their desirous crop.

\section{References}

1. CABI (2021) Invasive species compendium. Sclerotium rolfsii (Athelia rolfsii).

2. Aycock R (1966) Stem rot and other diseases caused by Sclerotium rolfsii. NC Agric EXp Stn Tech Bull 174: 202.

3. Mayee CD, VV Datar (1988) Diseases of Groundnut in Tropic. Rev Trop Plant Path 5: 85-118.

4. Singh BP, JN Chand (1992) Assessment of losses of betelvine (Piper betel) caused by Sclerotium rolfsii in Jabalpur, India. Science and Culture 52(2): 544-547.

5. Dasgupta MK, NC Mandal (1989) Post- harvest pathology of perishables. IBH Publisher. 
6. Nazerian E, SP Ashnaei (2021) Occurrence of Sclerotium rolfsii affecting arum lily in Asia. Journal of Plant Pathology 103: 655.

7. Parkpian A (1980) Studies on seedling blight of rice caused by Sclerotium rolfsii. Thesis submitted to Graduate school, Kasetsart Univ. Bangkok, p. 94

8. Borkar SG, KN Choudhary (2007) Seedling growth inhibition index- A technique for identifying foot-rot resistance in wheat. SAARC journal of Agricultre 5(1): 87-90.

9. Singh HB, DN Upadhyay, L Sahar (1987) Collar rot of pigeon pea in Nagaland, India. International Pigeonpea Newsletter 6: 52-53.

10. Sarma BK, UP Singh (2003) Ferulic acid may prevent infection of Cicer arietinum by Sclerotium rolfsii. World J Microbial Biotech 19: 123-127.

11. Borkar SG (1992) Influence of Weather on S.rolfsii root rot and wilt in Soyabean. Indian J of Mycology and Plant Pathology 22(2): 193-194.

12. Patil RP, KS Jagadeesh, PU krishnarajapur, JH Kulkarni (1998) Bacterization of Groundnut with P. fluorescens for the control of collar rot caused by Sclerotium rolfsii. Karnataka J Agric Sci 11: 423-425.

13. Khan RU, SJ Kolte (2002) Some seedling diseases of Rep-seed Mustard and their control. Indian Phytopath 55(1): 102-103.

14. Bhatia S, RC Dubey, DK Maheshwari (2005) Enhancement of plant growth and suppression of collar rot of sunflower caused by Sclerotium rolfsii through Fluorescent Pseudomonas. Indian Phytopath 58(1): 1724.

15. Prabhu HV, PC Hiremath (2003) Bio efficacy of fungicides against collar rot of cotton caused by Sclerotium rolfsii. Karnataka J Agric Sci 16(4): 576-579.

16. Prasad BK, SP Thakur, A Sinha (1986) Influence of nutritional factor, $\mathrm{pH}$, and temperature on growth of Sclerotium rolfsii. Isolated from tomato fruit. J Mycol and Plant Path 16(2): 209-212.

17. Punja ZK, JD Carter, GM Campbell, EL Rossell (1986) Effect of calcium and nitrogen fertilizerz, fungicides, and tillage practices on incidence of Sclerotium rolfsii on processing carrots. Plant Dis 70(9): 819-824.

18. Kulkarni NB, O Ahmed (1967) Studies on the basidial formations by Sclerotium rolfsii. A modified medium inducing basidial stage by wheat isolate of S. rolfsii. Science and Culture 34(2): 127-128.

19. Singh RP, SK Gandhi (1991) Effect of soil pH and temperature on seedling mortality of guar caused by Sclerotium rolfsii and its fungicidal control. Indian Phytopath 44(3): 360-365.

20. Solunke BS, BM Kareppa, LV Gangawane (2001) Survival ability of carbendazim resistant Sclerotium rolfsii in mixed population. Indian J Plant Pathol 54(4): 486-487.

21. Das Srikanta, SK Raj (2004) Management of Sclerotium root rot of sugarbeet through seed soaking with non-conventional chemicals. Indian Phytopathology 57(1): 112-113.

22. Adandonon A (2000) Damping off of cowpea in Benin and South Africa. M.Sc thesis, Univ of Pretoria, South Africa.

23. Prakash O, UN Singh (1976) Basal rot of mango seedlings caused by Sclerotium rolfsii. Indian J of Mycol and Plant Pathol 6: 75.

ISSN: 2574-1241

DOI: 10.26717/BJSTR.2021.38.006151

SG Borkar. Biomed J Sci \& Tech Res

This work is licensed under Creative Commons Attribution 4.0 License

Submission Link: https://biomedres.us/submit-manuscript.php
24. Siddaramaiah AL (1988) Stem, Sheath and leaf rot disease of cardamom caused by Sclerotium rolfsii from India. Current Research 17(4): 51.

25. Raut AS, DN Kshirsagar, KC Kurade, SW More, ST Ingle (2016) Occurrence of major diseases on medicinal and aromatic plants and their relationship with weather parameters. BioInfolet 13(2b): 409-419.

26. Singh A, HB Singh (2004) Control of collar rot in mint caused by Sclerotium rolfsii using biological means. Current Science 87(3): 362366.

27. Naidu PH (2000) Crossandra, a new host record for Sclerotium rolfsii. Indian Phytopathol 53(4): 496-497.

28. Yang XM, JH Wang, SP Qu, LH Wang (2007) First report of Southern blight caused by Sclerotium rolfsii on Lily in China. Plant Disease 91(1): 109.

29. Sankaran KV, EJ Maria Florence, Jyoti K Sharma (2007) Two new diseases of forest tree seedlings caused by Sclerotium rolfsii in India. Forest Pathology 14(4-5): 318-320.

30. Amaradasa BS, A Turner, S Lowman, C Mei (2020) First report of Southern blight caused by Sclerotium rolfsii in industrial hemp in south Virginia. Plant Disease 104(5): 1563-1563.

31. Backman PA, Rodriguez Kabana R, Caulin MC, Beltramini E, Ziliani $N$ (1981) Using the soil-tray technique to predict the incidence of Sclerotium rot in sugar beets. Plant Disease 65(5): 419-421.

32. Harlton CE, CA Levesque, ZK Punja (1995) Genetic diversity in Sclerotium (Athelia) rolfsii and related species. Phytopathology 85(10): 1269-1281.

33. Nalim FA, JL Sattar, KE Woodard, S Segner, NP Keller (1995) Mycelial compatibility groups in Texas peanut field population of Sclerotium rolfsii. Phytopatholgy 85(12): 1507-1512.

34. Okabe I, C Morikawa, N Matsumoto, K Yokoyama (1998) Variation in Sclerotium rolfsii isolates in Japan. Mycoscience 39(4): 399-407.

35. Punja ZK, LJ Sun (2001) Genetic diversity among mycelial compatibility groups of Sclerotium rolfsii and S. delphinii. Mycol Res 105: 537- 546.

36. Sarma BK, UP Singh, KP Singh (2002) Variability in Indian isolates of Sclerotium rolfsii. Mycologia 94(6): 1051-1058.

37. Shukla R, AK Pandey (2007) Diversity in isolates of S.rolfsii from central India. J Mycol and Plant Pathol 37(3).

38. Gawande SP (2009) Variation in Sclerotium rolfsii in Western Maharashtra. Ph.D. thesis submitted to Mahatma Phule Agriculture University, Rahuri, India, pp. 154.

39. Gawande SP, SG Borkar, VP Chimote (2013) Variation in growth and oxalic acid production by different crop isolates of Sclerotium rolfsii. J Mycopathological Research 51(1): 95-100

40. Gawande SP, SG Borkar, VP Chimote, AK Sharma (2013) Determination of genetic diversity in sclerotium rolfsii and Sclerotium delphinii by using RAPD and ISSR markers. Vegetos 26(SP): 39-44.

41. NandiS, SHembaram, S Datta (2017) Hostinfection beyond the traditional range of Sclerotium rolfsii with Physalis minima. Bioinformation 13(10): 333-338.

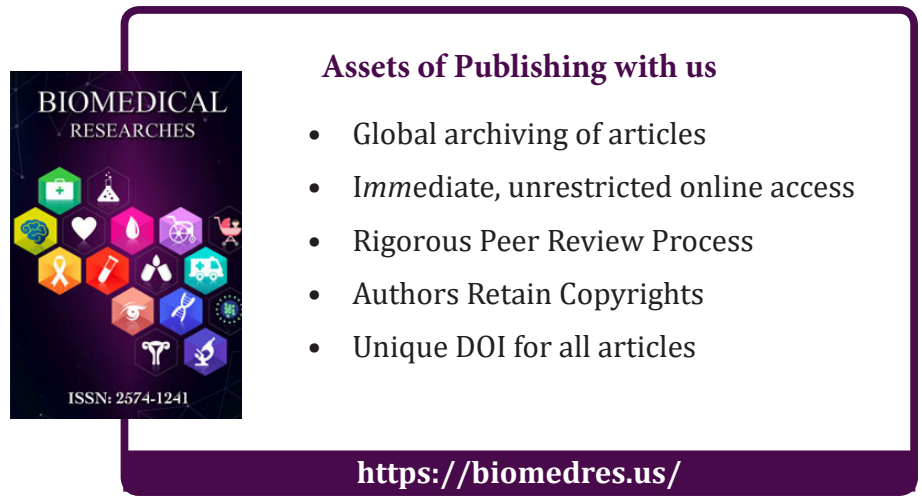

